How to cite: Martonoş, I.M., Matei, A.T., Roșu, C. (2020) Ventilation and Indoor Air Quality in Learning Environments from Cluj-Napoca (Romania). 2020 "Air and Water - Components of the Environment" Conference Proceedings, Cluj-Napoca, Romania, p. 23-36, DOI: 10.24193/AWC2020_03.

\title{
VENTILATION AND INDOOR AIR QUALITY IN LEARNING ENVIRONMENTS FROM CLUJ-NAPOCA (ROMANIA)
}

\author{
Ildiko Melinda MARTONOŞS ${ }^{1}$, Andrei TiberiuMATEI ${ }^{1}$, Cristina ROȘU ${ }^{1 *}$
}

DOI: 10.24193/AWC2020_03

\begin{abstract}
In today's modern society, people spend much of their time in closed spaces (at home, at work, at school etc.), the quality of the air inside these spaces being very important for the occupants' health. This study monitored the indoor air quality in classrooms, seminar and office rooms, within the Faculty of Environmental Science and Engineering from Cluj-Napoca and outside the building (the inner courtyard). Two air sampling campaigns were carried out, one during the cold period (March 2019), and the other during the warm period (April 2019). The monitored substances were: carbon dioxide $\left(\mathrm{CO}_{2}\right)$, particulate matter $\left(\mathrm{PM}_{2.5}, \mathrm{PM}_{10}\right)$, formaldehyde, total volatile organic compounds (TVOC) as well as the temperature and relative humidity of the studied rooms, respectively the outside courtyard, using BQ16 and BQ30 Trotec equipment's. The average values for $\mathrm{CO}_{2}$ concentration exceeded the recommended 1,000 ppmv ASHRAE standard value, especially after a period when the rooms were not ventilated and the number of people inside increased. Concentrations of $\mathrm{PM}_{2.5}$ and $\mathrm{PM}_{10}$ were below the recommended ASHRAE standard value, of $25 \mu \mathrm{g} / \mathrm{m}^{3}$ for $\mathrm{PM}_{2.5}$ and $50 \mu \mathrm{g} / \mathrm{m}^{3}$ for $\mathrm{PM}_{10}$, so indoor air quality is not inappropriate for this reason. Formaldehyde and TVOC concentrations measured in the monitored rooms, did not exceeded the recommended standard values. Their concentrations were lower outside than inside, so it can be considered that their source was an internal one and their concentrations increased as the number of people in the room increases. In the seminar room the CDI (Chronic Daily Intake) value for formaldehyde has the value $0.052 \mathrm{mg} / \mathrm{kg} \cdot$ day, slightly exceeding the recommended value by U.S.EPA (1989), of $0.045 \mathrm{mg} / \mathrm{kg} \cdot$ day.
\end{abstract}

Keywords: indoor air quality, Cluj-Napoca, formaldehyde, particulate matter, $\mathrm{CO}_{2}$

\section{INTRODUCTION}

Indoor air quality is influenced by the internal sources of pollution, the characteristics of the buildings and the lifestyle of the residents, as well as by the external pollution. The term "air pollution" refers not only to ambient, outdoor pollution, but also to indoor pollution, within enclosed spaces, such as schools, building offices, homes and other workplaces. The indoor pollution can occur from

\footnotetext{
${ }^{1}$ Babeş-Bolyai University, Faculty of Environmental Science and Engineering, 30, Fantanele Street, Cluj-Napoca, Romania, e-mail: cristina.rosu@ubbcluj.ro
} 
a huge variety of chemicals, products, even pets. Some more common sources of indoor air pollution are represented by tobacco smoke, mold, chemicals released from household products or synthetic fabrics, different paintings or dyes (Iorga, 2016).

In the last decades, numerous studies have focused on air quality in residential and non-residential buildings (offices, schools etc.). Indoor air quality (IAQ) represents a great concern also for the governmental, regional and worldwide organizations (for example: American Society of Heating, Refrigerating and Air Conditioning Engineers - ASHRAE; World Health Organisation - WHO), due to its impact on human health. These organizations and many national organizations have stipulated standards and guideline values to limit the exposure of humans to different air contaminants. The most frequent air pollutants which contribute to a poor IAQ are: carbon dioxide $\left(\mathrm{CO}_{2}\right)$, carbon monoxide $(\mathrm{CO})$, total volatile organic compounds (TVOC), formaldehyde $(\mathrm{HCOH})$, nitrogen dioxide $\left(\mathrm{NO}_{2}\right)$, sulphur dioxide $\left(\mathrm{SO}_{2}\right)$ and particulate matter $\left(\mathrm{PM}_{2.5}\right.$ and $\left.\mathrm{PM}_{10}\right)$ (Abdul-Wahab et al., 2015).

Air quality inside buildings for educational purposes, such as classrooms or seminar rooms, can significantly affect the activity of students, being exposed to different pollutants generated inside, such as: $\mathrm{CO}_{2}$, formaldehyde, volatile organic compounds, particulate matter $\mathrm{PM}_{2.5}$ and $\mathrm{PM}_{10}$ etc., but also to atmospheric pollutants from external sources (radon, suspended particles, volatile organic compounds etc.). Poor IAQ has long been recognized as a cause of occupant discomfort, is the cause of adverse health effects, increased absenteeism at work or school, and impaired cognitive performance (Johnson et al., 2018).

Several studies on the IAQ topic have indicated that ventilation is often inadequate in inside spaces/classrooms, where $\mathrm{CO}_{2}$ concentrations are over 3000 ppmv. Although $\mathrm{CO}_{2}$ is not an indoor air pollutant, high concentrations of this gas represents an indicator of insufficient ventilation. The concentration of $\mathrm{CO}_{2}$ inside depends mainly on the human factor and the air flow supplied from the outside (dilution). Indoor $\mathrm{CO}_{2}$ concentrations are usually below 2,000-2,500 ppmv, but can reach 4,000-5,000 ppmv in certain situations (Turanjanin et al., 2014; Zhang et al., 2016). ASHRAE recommends a fresh air supply rate of $10 \mathrm{l} / \mathrm{s} /$ person for offices and $8 \mathrm{l} / \mathrm{s} /$ person for classrooms (Hou et al., 2015).

Turanjanin et al. (2014) monitored the indoor and outdoor $\mathrm{CO}_{2}$ concentrations during the cold season, in five naturally ventilated primary schools in Serbia, located in rural and urban areas, where students learn in two shifts. According to the EN 15251 standard, the ventilation rates for schools are $(4-10) \mathrm{L} / \mathrm{h} /$ person, while the values obtained by measurements were in the range $(0.8-4.1)$ $\mathrm{L} / \mathrm{h} /$ person, which indicate very poor ventilation. In more than $50 \%$ of the time when the students were in the classroom, the $\mathrm{CO}_{2}$ concentration reached a maximum value of about 3,600 ppmv at the end of the morning shift, indicating inadequate ventilation.

Ghita and Catalina (2015) conducted a detailed research in three schools (new, old and a renewed building) from the Mateeşti (Vâlcea County, Romania) rural area. In all three schools the measured values varied between $2,000-3,000$ ppmv, in 
certain situations the concentration was close to $5,000 \mathrm{ppmv}$ (the old building recorded the highest values).

The air quality inside the schools also concerned US researchers, Johnson et al. (2018) conducted measurements in 12 primary schools in the Oklahoma City metropolitan area, in spring, summer and autumn. The results indicated that the level of pollutants independent of the occupants of the rooms is extremely low, and the level of pollutants associated with vehicles from outside is very small to insignificant. In many cases, however, inadequate ventilation was found, increasing $\mathrm{CO}_{2}$ concentration, to the detriment of cognitive performance.

Kalimeri et al. (2016) determined the pollutants to which children are exposed in two primary schools and a kindergarten located in Kozani, Greece. All the schools were naturally ventilated and during the cold season they used central heating. According to the obtained results, the pollutants loading of the indoor air was within acceptable limits for the following pollutants: $1.5-9.4 \mathrm{mg} / \mathrm{m}^{3}$ for benzene; 2.3-28.5 mg/m $\mathrm{m}^{3}$ for formaldehyde; $4.6-43 \mathrm{mg} / \mathrm{m}^{3}$ for $\mathrm{NO}_{2}$ (the construction materials representing the major source of pollution). Very low ventilation rates were observed $(0.1-3.7 \mathrm{~L} / \mathrm{s} /$ person), indicating inadequate ventilation and possible indoor air quality problems, which require intervention measures.

Stableet al. (2017) conducted a research on the efficiency of the natural ventilation strategies on the indoor air quality, in schools from central Italy. In this scope, the $\mathrm{CO}_{2}$ emissions and $\mathrm{PM}$ concentrations were monitored, their levels being compared with the corresponding external levels. The results showed that the aeration strategy influences the pollutants detected internally, depending on their size, origin and dynamics. Longer ventilation periods may lead to lower $\mathrm{CO}_{2}$ indoor concentrations and similarly lower concentrations of other gases generated indoors (such as radon and TVOC). At the same time, high levels of ultrafine particles $\mathrm{PM}_{2.5}$ and $\mathrm{PM}_{10}$ (and other vehicle-related pollutants) were recorded indoors, due to the infiltration from the outside. The reduction of all pollutants cannot be achieved using only natural ventilation.

Regarding the impact of thermal rehabilitation impact on indoor carbon dioxide releases, Kapalo et al. (2018) concluded in their study that the rehabilitation processes (thermal insulation) decreases the production of $\mathrm{CO}_{2}$, and the releases of $\mathrm{CO}_{2}$ were reduced to a final value smaller with $40 \%$ compared to the initial footprint, before the thermal rehabilitation of the building.

The physiological responses due to typically occurring levels of $\mathrm{CO}_{2}$ were studied by Zhang et al. (2016). They observed that at levels of 3,000 ppmv of metabolically generated $\mathrm{CO}_{2}$, the diastolic blood pressure increased and the cognitive responses decreased.

High levels of formaldehyde (mostly in new and renewed buildings) increases when inside temperature is high $\left(\right.$ over $26^{\circ} \mathrm{C}$ ), the level of TVOC's and formaldehyde is particularly a concern in low-come communities (Dodson et al., 2017; Liu et al., 2017). Formaldehyde and VOC's can represent a risk to human health, when are present in high concentrations, including a non-cancer or cancer 
risk (brain liver, lung, blood, kidney and biliary tract cancers) (WHO, 2000; He et al., 2015; Chang et al., 2019). High levels from these pollutants have as effects headache, cough, nausea, sever liver poisoning, asthma and other respiratory effects (Dai et al., 2017; Rumchev et al., 2007).

Regarding particulate matters, they generally originate antropogenically in cities, from industrial emissions, vehicular traffic and long-range transport. The PM particles represent a major concern due to their potential health impact. The epidemiological studies show a link between exposure to PM and respiratory symptoms and reduced pulmonary function, or even increased mortality (Pope and Dockery, 2006; Ramos-Bonilla et al., 2010).

The purpose of this study was to realize an assessment of the indoor air quality in learning spaces (classrooms) from learning environments (university) from ClujNapoca and to identify the possible impact on health of the inhabitants.

\section{DATA AND METHODS}

\subsection{Building characteristics}

The chosen building for this study is located on 30 Fântânele Street, at the Faculty of Environmental Science and Engineering, Babeş-Bolyai University in Cluj-Napoca (Romania). For the measurements, 3 rooms were chosen, all situated at the ground floor, all orientated to the inner courtyard. The study was conducted between March and April 2019. The building was built between 1950 and 1953, the walls being made of brick (two rows, with a thickness of $45-50 \mathrm{~cm}$ ), naturally ventilated (through windows and PVC doors).

Table 1 and 2 presents the characteristics of the investigated rooms.

Table 1. Room features - March 2019

\begin{tabular}{|c|c|c|c|c|c|c|}
\hline Room & $\begin{array}{c}\text { Volume } \\
\left(\mathrm{m}^{3}\right)\end{array}$ & $\begin{array}{l}\text { Surface } \\
\left(\mathbf{m}^{2}\right)\end{array}$ & $\begin{array}{l}\text { No. people } \\
\text { (average) }\end{array}$ & $\begin{array}{c}\mathrm{T}_{\mathrm{in}}\left({ }^{0} \mathrm{C}\right) \\
\text { (average) } \\
*\end{array}$ & $\begin{array}{c}\mathbf{T}_{\mathrm{ex}}\left({ }^{0} \mathrm{C}\right) \\
\text { (average) } \\
* *\end{array}$ & $\begin{array}{c}\mathrm{RH}_{\text {in }}(\%) \\
\text { (average) } \\
* * *\end{array}$ \\
\hline A.1.14 (classroom) & 285 & 89 & 7.7 & 22.4 & 13.1 & 42.9 \\
\hline A.1.15 (office room) & 70 & 22 & 2 & 23 & 15.3 & 40.7 \\
\hline A.1.16 (seminar room) & 135 & 42 & 6.6 & 23.2 & 9.8 & 40.4 \\
\hline
\end{tabular}

* $\mathrm{T}_{\text {in }}-$ indoor temperature; $\mathrm{T}_{\mathrm{ex}}-$ outdoor temperature, $\mathrm{RH}_{\mathrm{in}}-$ indoor relative humidity

Table 2. Room features - April 2019

\begin{tabular}{|c|c|c|c|c|c|c|}
\hline Room & $\begin{array}{c}\text { Volume } \\
\left(\mathrm{m}^{3}\right)\end{array}$ & $\begin{array}{c}\text { Surface } \\
\left(\mathbf{m}^{2}\right)\end{array}$ & $\begin{array}{l}\text { No. people } \\
\text { (average) }\end{array}$ & $\begin{array}{c}\mathbf{T}_{\text {in }}\left({ }^{0} \mathrm{C}\right) \\
\text { (average) }\end{array}$ & $\begin{array}{c}\mathbf{T}_{\text {ex }}\left({ }^{0} \mathrm{C}\right) \\
\text { (average) }\end{array}$ & $\begin{array}{l}\mathrm{RH}_{\text {in }}(\%) \\
\text { (average) }\end{array}$ \\
\hline A.1.14 (classroom) & 285 & 89 & 3.4 & 21.6 & 15.8 & 39.3 \\
\hline A.1.15 (office room) & 70 & 22 & 1.8 & 23.3 & 15 & 33.4 \\
\hline A.1.16 (seminar room) & 135 & 42 & 5.9 & 23.03 & 14 & 30.3 \\
\hline
\end{tabular}




\subsection{Methodology and analysis}

The concentrations of the following substances were monitored: $\mathrm{CO}_{2}, \mathrm{PM}_{2.5}$, $\mathrm{PM}_{10}$, formaldehyde, TVOC, as well as the values of temperature and relative humidity of the studied rooms, measurements were carried out indoor and also outdoor, also because these two environments are linked.

The outside conditions during the measurements were the following: in the cold period, respectively in March 2019, the minimum temperature was $9.8^{\circ} \mathrm{C}$ and the maximum $15.3{ }^{\circ} \mathrm{C}$; during the warm period, respectively in April 2019, the minimum temperature was $14^{\circ} \mathrm{C}$ and the maximum $15.8^{\circ} \mathrm{C}$.

Measurements of $\mathrm{CO}_{2}, \mathrm{PM}_{2.5}, \mathrm{PM}_{10}$ were performed using a $\mathrm{BQ} 30$ multifunctional measuring device for home climate monitoring from Trotec (with a laser integrated measuring cell, class $3 \mathrm{R}$ laser, $780 \mathrm{~nm}, 1.5-3 \mathrm{~mW}$ ) and for formaldehyde and TVOC using a BQ16 detector also from Trotec.

Since the quality of indoor air is influenced by a very large and varied number of pollution sources, such as the number of people in the room, the number, size and type of material from which the furniture in the room is made, the building materials used to decorate the walls / floors (adhesives, paints, solvents, etc.), as well as external air pollutants (industry, traffic, combustion, etc.), all the characteristics of the rooms were noted and taken into consideration, such as: surface, number of persons, type of furniture and others (see some characteristics in table 1 and 2).

In order to characterize indoor air quality, the Air Exchange Rate (AER) was calculated using the following mathematical formula (Hou et al., 2015):

where:

$$
A E R=\frac{1}{\Delta t} \cdot \ln \left\{\left[c\left(t_{1}\right)-c\left(t_{\text {out }}\right)\right] /\left[c\left(t_{2}\right)-c\left(t_{\text {out }}\right)\right]\right\}
$$

AER - represents the number of air exchanges per hour;

$\mathrm{c}(\mathrm{t} 2)$-indoor $\mathrm{CO}_{2}$ concentration at the beginning of sampling $\mathrm{t} 1$;

$\mathrm{c}(\mathrm{t} 1)$-indoor $\mathrm{CO}_{2}$ concentration at the end of sampling $\mathrm{t} 2$;

$\mathrm{c}_{\text {out }}-$ outdoor $\mathrm{CO}_{2}$ concentration (natural background);

$\Delta \mathrm{t}=\mathrm{t} 2-\mathrm{t} 1$ (time difference in hours).

Ventilation rates can be calculated based on $\mathrm{CO}_{2}$ measurements performed indoor and outdoor, based on the fact that ventilation is the only significant process for decreasing the $\mathrm{CO}_{2}$ concentration inside. The level of $\mathrm{CO}_{2}$ in a room is directly proportional to the number of occupants, as the occupants represent the major source.

To establish the possible impact of formaldehyde on human health the Chronic Daily Intake (CDI) for formaldehyde was calculated based on the obtained results, using the following formula (US EPA, 1989):

$$
C D I\left(\mathrm{mg} \cdot \mathrm{kg}^{-1} \cdot \mathrm{day}^{-1}\right)=\frac{C A \cdot I R \cdot E T \cdot E F \cdot E D}{B W \cdot A T}
$$


where:
CA - formaldehyde concentration $\left(\mathrm{mg} / \mathrm{m}^{3}\right)$
IR - inhalation rate, $\left(\mathrm{m}^{3} / \mathrm{h}\right) \rightarrow 0.79\left[\mathrm{~m}^{3} / \mathrm{h}\right]$
BW - body weight, $(\mathrm{kg}) \rightarrow 60 \mathrm{~kg}$
ET - shutter speed, (h/day) $\rightarrow 6 \mathrm{~h} /$ day
$E F$ - frequency of exposure, (days/year) $\rightarrow 150$ days/year
ED - exposure time, (years) $\rightarrow 4$ years
AT - averaging time (years) $\rightarrow 70$ years

\section{RESULTS AND DISCUSSIONS}

The monitored rooms were different in size and conditions (as shown in table 1 and 2), as the scope of this study was to evaluate the IAQ, in different conditions and room sizes, as in a warmer and colder period. The comfort parameters $(\mathrm{T}, \mathrm{RH})$ were continuously monitored during the investigated period. The indoor average temperatures measured in March and April 2019 were similar. In April 2019, the values for RH decreased, as the outside temperature increased and were less precipitation.

ANSI/ASHRAE 55-2004 Standard, recommends the following temperatures for indoor comfort: $23-26{ }^{\circ} \mathrm{C}$ for non-heating period and $20-23^{\circ} \mathrm{C}$ for heating period, with an indoor RH of $30-60 \%$. The recorded indoor temperature and humidity, in the investigated rooms, were within these recommended values by the ANSI/ASHRAE standards.

\section{1. $\mathrm{CO}_{2}$ concentration values}

Figure 1 shows the average indoor levels of $\mathrm{CO}_{2}$, ranging from 864.6 to $1,182.8$ ppmv in March, with the highest values measured in Room A.1.16 (seminar room). In April the values decreased (695.7-879.2 ppmv), due to the fact that outside temperature increased and the ventilation was made more frequent.

The highest indoor $\mathrm{CO}_{2}$ concentration was measured in room A.1.16 in March 2019 , with a value of 2,329 ppmv (number of occupants 12). The ASHRAE guideline value, of 1,000 ppmv, was exceeded in two monitored classrooms (A1.14 and A1.16), in the colder period. Average outside concentrations of $\mathrm{CO}_{2}$ ranged from 335.3 to 425.5 ppmv in March 2019 and from 331 to 375 ppmv in April 2019, in the monitored period no significant precipitations were recorded.

Based on the obtained results, we observed a constant tendency of increasing $\mathrm{CO}_{2}$ concentration from the beginning of the day, until the end of the day, being recorded variations (decreases or increases), depending on the number of people in the room and by ventilation. 


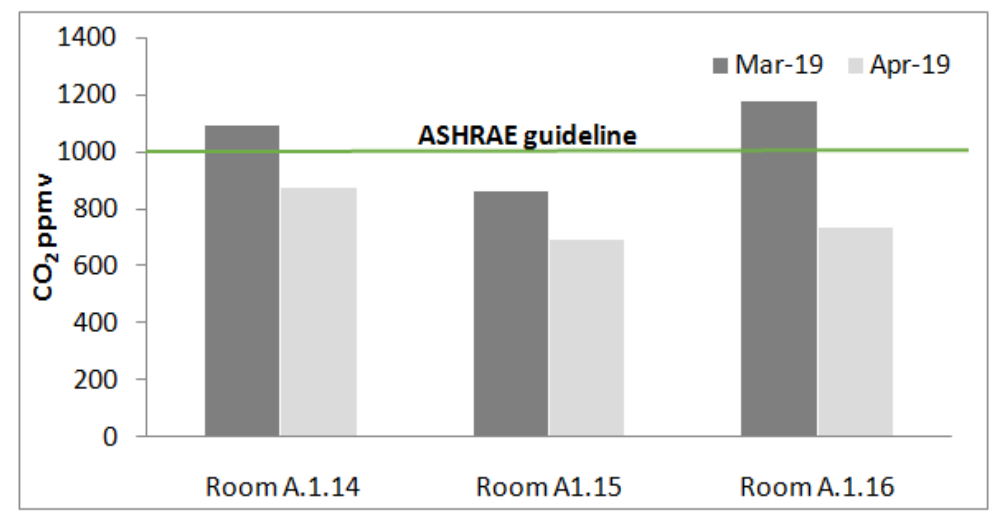

Fig. 1. Indoor $\mathrm{CO}_{2}$ variations in the investigated rooms

If the room ventilation is inadequate, the air quality deteriorates and the concentrations of pollutants from indoor sources increase.

Similar results were obtained also in other studies, such as that carried out by Turanjanin et al. (2014) in schools from Serbia, where average $\mathrm{CO}_{2}$ concentrations where over 1,000 ppmv (most of them around 1,500 ppmv). Hou et al. (2015) recorded average $\mathrm{CO}_{2}$ values of 1,285-1,659 ppmv in schools from China, and Ghita and Catalina (2015) measured values of 2,000-3,000 ppmv in schools from Vâlcea County, Romania.

The Air Exchange Rate (AER) and ventilation rate (VR) were calculated based on the measurements of $\mathrm{CO}_{2}$ carried out indoors and outdoors, based on the fact that ventilation is the only significant process for decreasing the $\mathrm{CO}_{2}$ concentration inside, using mathematical equation number 1 . The ventilation of the monitored rooms was carried out under different conditions (only with the open window, window and door open, respectively only with the open door), for different periods of time (e.g. 5 minutes, 30 minutes, 1 hour etc.).

The AER and VR calculated values are presented in table 3, for each monitored room, for the warmer and colder seasons. Ventilation rates in all monitored rooms, both in the cold and in the warmer season, are below $5 \mathrm{~L} / \mathrm{s} /$ person. In A.1.14 and A.1.15 rooms, the ventilation rates in the colder season are lower than those in the warmer season, while in room A.1.16 is vice versa. Low ventilation rates $(<5 \mathrm{~L} / \mathrm{s} /$ person - value recommended by ASHRAE 62-2001 Standard), indicate inadequate ventilation and possible indoor air quality problems, which require intervention measures.

The ventilation rates calculated by Turanjanin et al. (2014), in their studies in schools from Serbia, were between $0.8-4.1 \mathrm{~L} / \mathrm{s} /$ person, Kalimeri et al. (2016) obtained ventilation rates between $0.1-3.7 \mathrm{~L} / \mathrm{s} /$ person (in schools from Greece). Hou et al. (2015), obtained values below $1 \mathrm{~L} / \mathrm{s} /$ person (in schools from China), and in Vâlcea County (Romania) schools the ventilation rates varied between $0.7-2.4$ $\mathrm{L} / \mathrm{s} /$ person. 
Table 3. Calculated air exchange rate (AER) and ventilation rate (VR) values

\begin{tabular}{lccc}
\hline \multicolumn{1}{c}{ Room } & Period & $\begin{array}{c}\text { AER } \\
\left(\mathbf{h}^{\mathbf{- 1}}\right)\end{array}$ & $\begin{array}{c}\text { VR } \\
(\mathbf{L} / \mathbf{s} / \mathbf{p e r s} .)\end{array}$ \\
\hline A.1.14 (classroom) & March 2019 & 0.31 & 3.14 \\
& April 2019 & 0.20 & 4.54 \\
A.1.15 (office room) & March 2019 & 0.30 & 2.92 \\
& April 2019 & 0.41 & 4.43 \\
A.1.16 (seminar room) & March 2019 & 0.60 & 3.41 \\
& April 2019 & 0.11 & 0.70 \\
ASHRAE guideline & & & $\mathbf{5}$ \\
\hline
\end{tabular}

\subsection{TVOC and formaldehyde concentration values}

Formaldehyde was detected outside only in the warm season, with only one value above zero, respectively 0.01 ppmv, on April 04, 2019 (sunny day).

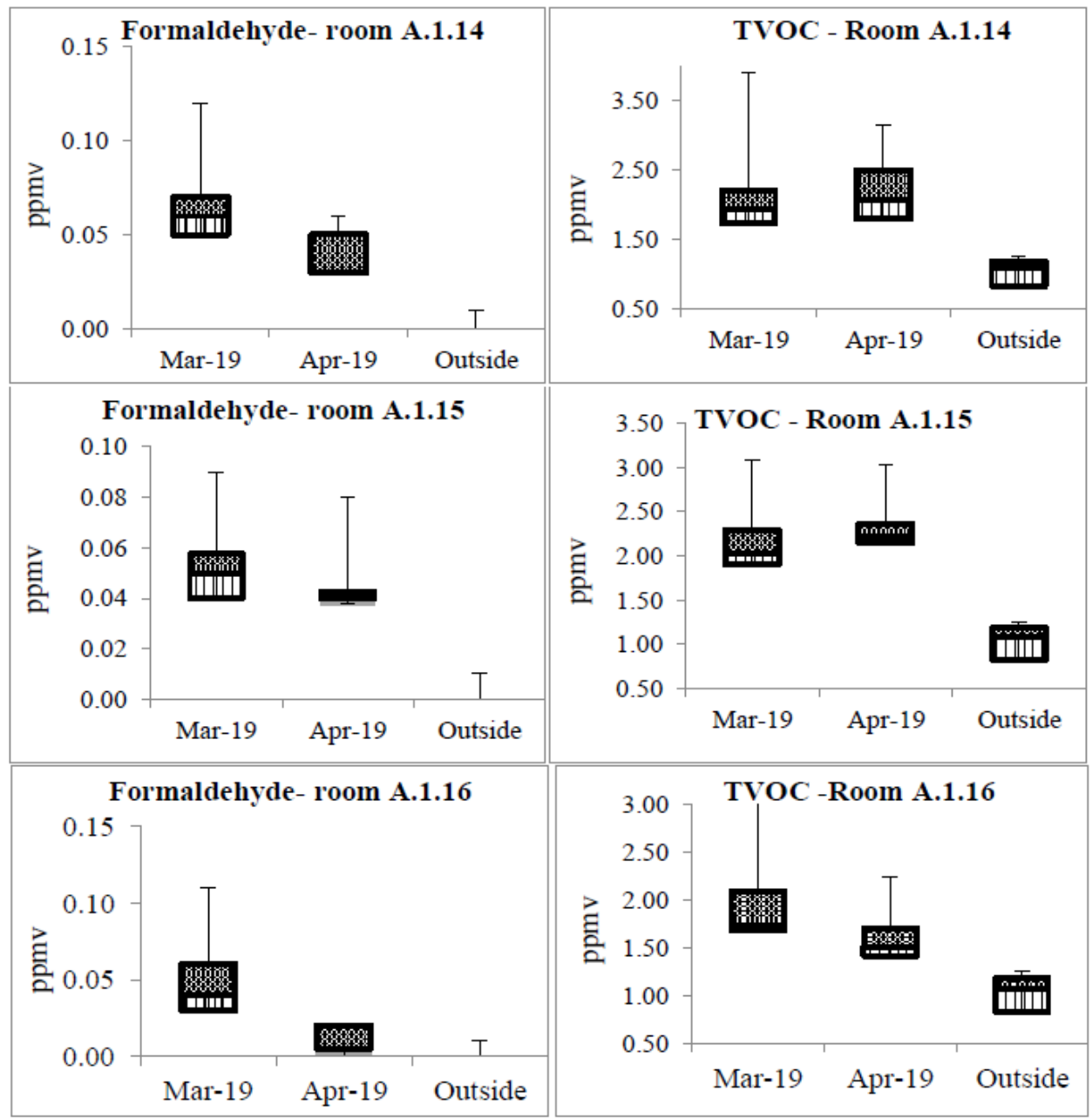

Fig. 2. Indoor and outdoor TVOC and formaldehyde concentrations 
Formaldehyde was detected in the monitored rooms, this because the inside furniture and wooden products are containing formaldehyde-based resins as well because of different textiles. During the cold season, indoor formaldehyde concentrations ranged from 0.01 to $0.12 \mathrm{ppmv}$, while in the warmer season varied between 0,01 and 0.08 ppmv (excepting four cases, when formaldehyde was not detected) (see figure 2).

Also, inside and outside values are below the limit allowed by the ASHRAE standard of $0.085 \mathrm{ppmv}$. Given that the values inside are higher than those outside, we can say that formaldehyde sources are internal. The indoor concentrations of formaldehyde in the monitored rooms were influenced by the ventilation of the rooms and temperature. With the introduction of fresh air into the room, the formaldehyde concentration decreased and in the absence of ventilation the concentrations increased.

An increase in the formaldehyde concentration was observed with the increase of the number of people in the room, correlated with the lack of ventilation.

A contaminated environment can cause health problems and provoke different symptoms, such as coughing, headache, fatigue, eyes and nose irritation, dizziness and others (Madureira et al., 2015), when the exposure is of long term the health effects could be more destructive (cancer, neurogical and chronic lung diseases (Kalimeri et al, 2016). Formaldehyde, one of the most known VOCs, is known as a human carcinogen (Kotzias et al., 2009).

The Chronic Daily Intake was calculated using the measured data's for formaldehyde, using mathematical equation no 2 , the obtained values are shown in table no. 4.

Table 4. Chronic Daily Intake (CDI) values ( $\mathrm{mg} / \mathrm{kg} \cdot \mathrm{day})$

\begin{tabular}{ccccccc}
\hline \multicolumn{3}{c}{ March 2019 } & \multicolumn{3}{c}{ April 2019 } \\
\hline Room & \multicolumn{2}{c}{ Formaldehyde } & $\begin{array}{c}\text { CDI } \\
(\mathrm{mg} / \mathrm{kg} \cdot \text { day })\end{array}$ & Formaldehyde & $\begin{array}{c}\text { CDI } \\
(\mathrm{mg} / \mathrm{kg} \cdot \text { day })\end{array}$ \\
& $p p m v$ & $\left(\mathrm{mg} / \mathrm{m}^{3}\right)$ & & $p p m v$ & $\left(\mathrm{mg} / \mathrm{m}^{3}\right)$ & \\
$\mathbf{A . 1 . 1 4}$ & 0.062 & 0.076 & $\mathbf{0 . 0 5 2}$ & 0.039 & 0.048 & 0.032 \\
$\mathbf{A . 1 . 1 5}$ & 0.050 & 0.061 & 0.042 & 0.039 & 0.048 & 0.032 \\
A.1.16 & 0.046 & 0.056 & 0.038 & 0.009 & 0.011 & 0.007 \\
\hline
\end{tabular}

The maximum CDI value established by the U.S. EPA in 1989 for formaldehyde is $0.045 \mathrm{mg} / \mathrm{kg}$. day. A value that exceeds this limit represents a health risk. Most of the results obtained in our study are below this value, only one result exceeds this value, in room A.1.14 $(0.052 \mathrm{mg} / \mathrm{kg} \cdot$ day $)$ in the colder period. This is probably due to the fact that in this room there are many benches and many overhung chairs, which, in sum, give a large area of emission for formaldehyde.

The average values recorded indoor for TVOC are higher than outside, also in the cold season, as in the warmer season. In similar studies, the following values for TVOC were obtained: Johnson et al. (2018) reported $0.00018-0.0941 \mathrm{mg} / \mathrm{m}^{3}$ 
values in Oklahoma schools; statistics made by Chi et al. (2016) for the 2007-2014 period shows a TVOC level of $0.51 \div 0.282 \mathrm{mg} / \mathrm{m}^{3}$ in urban indoor air.

\section{3. $P M_{2.5}$ and $P M_{10}$ concentration values}

The average concentrations of $\mathrm{PM}_{2.5}$ and $\mathrm{PM}_{10}$ measured inside the monitored rooms and outside are presented in figure 3.

The average concentrations for $\mathrm{PM}_{2.5}$ indoor, vary between $6.0-8.7 \mu \mathrm{g} / \mathrm{m}^{3}$ during the cold season, and between $5.8-12.0 \mu \mathrm{g} / \mathrm{m}^{3}$ in the warm season. Outside values in the cold season were between $2.5-9.5 \mu \mathrm{g} / \mathrm{m}^{3}$, respectively between 4.5 $13 \mu \mathrm{g} / \mathrm{m}^{3}$ in the warm season.

Medium concentrations for $\mathrm{PM}_{10}$ inside the monitored rooms vary between 10.7 and $16.4 \mu \mathrm{g} / \mathrm{m}^{3}$ in the cold season, between $10.2-24.8 \mu \mathrm{g} / \mathrm{m}^{3}$ in the warm season; while outdoor vary between $5-19 \mu \mathrm{g} / \mathrm{m}^{3}$ in the cold season and between $7.5-17$ $\mu \mathrm{g} / \mathrm{m}^{3}$ in the warm season.

In both, warm and cold seasons, $\mathrm{PM}_{2.5}$ and $\mathrm{PM}_{10}$ values were below the recommended values by the ASHRAE standard, respectively $25 \mu \mathrm{g} / \mathrm{m}^{3}$ for $\mathrm{PM}_{2.5}$ and $50 \mu \mathrm{g} / \mathrm{m}^{3}$ for $\mathrm{PM}_{10}$.

Analyzing the I/O ratio, we can see that for rooms A.1.14 and A.1.15, this is higher than one for both $\mathrm{PM}_{2.5}$ and $\mathrm{PM}_{10}$, so the concentrations of suspended particles indoor are higher than outdoor, meaning that their source is interior and not an external one. In the case of room A.1.16, in both cold and warm seasons, the $\mathrm{I} / \mathrm{O}$ ratio is subunit, so the concentrations of $\mathrm{PM}_{2.5}$ and $\mathrm{PM}_{10}$ indoor are lower than those outdoor, in this case we can talk about a possible external source.

\section{CONCLUSIONS}

This study gives an insight regarding indoor levels of $\mathrm{CO}_{2}$, formaldehyde, TVOC, $\mathrm{PM}_{2.5}$ and $\mathrm{PM}_{10}$ in two classrooms and one office from a university in ClujNapoca (Romania). The air quality inside the monitored rooms (classroom, office and seminar room) was sometimes inadequate, especially due to the increased $\mathrm{CO}_{2}$ concentration, above the level of $1000 \mathrm{ppmv}$ (value recommended by the ASHRAE standard). This was especially the case when the rooms were not properly ventilated and the number of people in the room increased. We can conclude that the levels of $\mathrm{CO}_{2}$ are related to the ventilation rate and to the number of occupants of the rooms (main $\mathrm{CO}_{2}$ source).

The calculated AER values indicated inadequate ventilation inside the rooms, the lack of adequate fresh air affecting the IAQ, possibly affecting the performance of students.

The measured concentrations for $\mathrm{PM}_{2.5}$ and $\mathrm{PM}_{10}$ were below the recommended levels by the ASHRAE standard $\left(25 \mu \mathrm{g} / \mathrm{m}^{3}\right.$ for $\mathrm{PM}_{2.5}$, respectively $50 \mu \mathrm{g} / \mathrm{m}^{3}$ for $\mathrm{PM}_{10}$ ), so the indoor air quality is not inadequate from this point of view. Regarding the source of $\mathrm{PM}_{2.5}$ and $\mathrm{PM}_{10}$, it was established that in the case of two rooms, the source was mostly interior (rooms A.1.14 and A.1.15), and in the case 


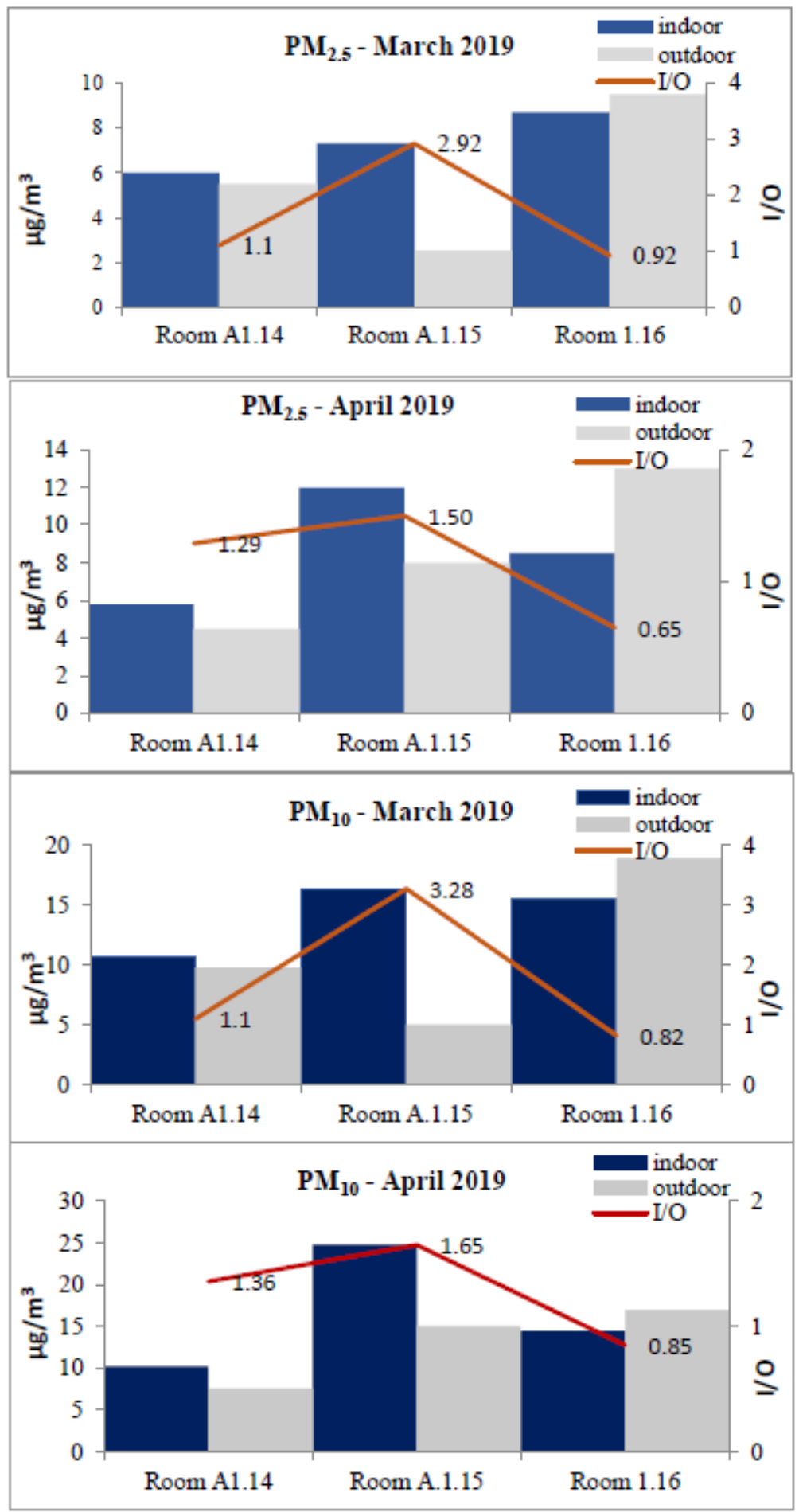

Fig.3. $P M_{2.5}$ and $P M_{10}$ indoor and outdoor concentrations and $I / O$ ratios 
of room A.1.16 the major source was an external one (the concentrations of $\mathrm{PM}_{2.5}$ and $\mathrm{PM}_{10}$ increased when the windows and doors were open). In the case of indoor sources, an increase of $\mathrm{PM}_{2.5}$ and $\mathrm{PM}_{10}$ was observed when the number of people increased and during pauses, probably due to the re-suspension phenomenon, due to the movement of students in the room.

The formaldehyde concentrations measured in the monitored rooms did not exceed the values recommended by the ASHRAE standard (of $0.085 \mathrm{ppmv}$ ). The formaldehyde and TVOC concentrations recorded outside were lower than those inside, concluding that the source was an internal one. An increase of them was observed with the increase in the number of people in the room, probably due to the used personal hygiene substances (deodorants, perfumes). But in order to be able to support these observations with certainty, a more detailed study would be necessary.

\section{REFERENCES}

1. Abdul-Wahab A. S., En S. C. F., Elkamel A., Ahmadi L., Yetilmezsoy K. (2015), A review of standards and guidelines set by international bodies for the parameters of indoor air quality. Atmospheric Pollution Research, 6(5), 751-767. https://doi.org/10.5094/APR.2015.084.

2. Chang T., Wang J., Lu J., Shen Z., Huang Y., Sun J., Xu H., Wang X., Ren D., Cao J. (2019), Evaluation of Indoor Air Pollution during the Decorating Process and Inhalation Health Risks in Xi'an, China: A Case Study, Aerosol and Air Quality Research, 19, 854-864, 2019, doi: 10.4209/aaqr.2018.07.0261.

3. Chi C., Chen W., Guo M., Weng M., Yan G., Shen X. (2016), Law and features of TVOC and formaldehyde pollution in urban indoor air. Atmos Environ., 132, 85-90, https://doi.org/10.1016/j.atmosenv.2016.02.043.

4. Dai H., Jing S., Wang H., Ma Y., Li L., Song W., Kan H. (2017), VOC characteristics and inhalation health risks in newly renovated residences in Shanghai, China. Sci. Total Environ., 577, 73-83.

5. Dodson R., Dodsona E., Udeskya J. O., Coltonb M. D., McCauleyc M., Camannd D. E., Yaud A. Y., Adamkiewiczb G., Rudela R. A. (2017), Chemical exposures in recently renovated low-income housing: Influence of building materials and occupant activities. Environment International, 109, 114-127, doi: 10.1016/j.envint.2017.07.007. Epub 2017 Sep 12.

6. Ghita S.A., Catalina T. (2015), Energy efficiency versus indoor environmental quality in different Romanian countryside schools, Energy and Buildings, 92, 140154, doi:10.1016/j.enbuild.2015.01.049.

7. He Z., Li G., Chen J., Huang Y., An T., Zhang C. (2015), Pollution characteristics and health risk assessment of volatile organic compounds emitted from different plastic solid waste recycling workshops. Environ. Int., 77, 85-94.

8. Hou Y., Liu J., Li J. (2015), Investigation of Indoor Air Quality in Primary School Classroms, Procedia Engineering, 121, 830-837, doi: 10.1016/j.proeng.2015.09.037.

9. Iorga G. (2016), Air Pollution Monitoring: A Case Study from Romania. Air Quality - Measurement and Modeling, 6, 135-162, http://dx.doi.org/10.5772/64611. 
10. Johnson D. L., Lynch R. A., Floyd E. L., Wang J., Bartels J. N. (2018), Indoor air quality in classrooms: Environmental measures and effective ventilation rate modeling in urban elementary schools. Building and Environment, 136, 185-197, https://doi.org/10.1016/j.buildenv.2018.03.040.

11. Kalimeri K.K., Saraga D.E., Lazaridis V.D., Legkas N.A., Missia D.A., Tolis E.I., Bartzis J.G. (2016), Indoor air quality investigation of the school environment and estimated health risks: Two-season measurements in primary schools in Kozani, Greece, Atmospheric Pollution Research, $\mathbf{X X X}, \quad 1-15$, http://dx.doi.org/10.1016/j.apr.2016.07.002.

12. Kapalo P., Bacotiu C., Domnita F., Zelenakova M. (2018), Apartment building thermal rehabilitation impact on indoor carbon dioxide releases. 2018 Air and Water Components of the Environment Conference Proceedings, 21-26, doi: 10.24193/AWC2018_03.

13. Kotzias D., Geiss O., Tirendi S., Barrero-Moreno J., Reina V., Gotti A., CiminoReale G., Casati B., Marafante E., Sarigiannis D. (2009), Exposure to multiple air contaminants in public buildings, schools and kindergartens e the European Indoor Air Monitoring and Exposure Assessment (AIRMEX) study. Fresen. Environ. Bull., 18 (5a), 670-681.

14. Liu L., Yu X., Dong X., Wang Q., Wang Y., Huang J. (2017), The Research on Formaldehyde Concentration Distribution in New Decorated Residential Buildings, Procedia Engineering, 205,1535-1541.

15. Madureira J., Paciencia I., Rufo J., Ramos E., Barros H., Teixeira P., de OliveiraFernandes E. (2015), Indoor air quality in schools and its relationship with children's respiratory symptoms. Atmos. Environ., 118, 145-156, https://doi.org/10.1016/j.atmosenv.2015.07.028.

16. Pope C.A., Dockery D.W. (2006), Health effects of fine particulate air pollution: lines that connect. J. Air Waste Manag. Assoc., 56(6), 709-742, doi: 10.1080/10473289.2006.10464485.

17. Ramos-Bonilla J.P., Breysse P.N., Dominici F., Geyh A., Tankersley C.G. (2010), Ambient air pollution alters heart rate regulation in aged mice. Inhal. Toxicol., 22, 330-339.

18. Rumchev K., Brown H. and Spickett J. (2007), Volatile organic compounds: Do they present a risk to our health? Rev. Environ. Health, 22, 39-56.

19. Stabile L., Dell'Isola M., Russi A., Massimo A., Buonanno G. (2017), The effect of natural ventilation strategy on indoor air quality in schools, Science of the Total Environment, 595, 894-902, doi:10.1016/j.scitotenv.2017.03.048.

20. Turanjanin V., Vucicevic B., Jovanovic M., Mirkov N., Lazovic I., (2014): Indoor $\mathrm{CO}_{2}$ measurements in Serbian schools and ventilation rate, Energy, 77, 290-296, doi:10.1016/j.energy.2014.10.028.

21. Zhang X., Wargocki P., Lian Z. (2016), Physiological responses during exposure to carbon dioxide and bio effluents at levels typically occurring indoors, Indoor Air, 27(1), 65-77, doi:10.1111/ina.12286.

22. ASHRAE, 2001.Ventilation for Acceptable Indoor Air Quality. American Society of Heating, Refrigerating and air-conditioning engineers, Inc., Atlanta (ANSI/ASHRAE Standard 62-2001).

23. ASHRAE, 2004. Thermal environmental Conditions for Human Occupancy. American Society of Heating, Refrigerating and air-conditioning engineers, Inc, Atlanta, GA (ANSI/ASHRAE Standard 55-2004). 
24. US Environmental Protection Agency, 1989, Risk Assessment Guidance for Superfund, vol.1. Human Health Evaluation Manual, Washington D.C. [EPA/540/189/002].

25. WHO (2000). Air quality guidelines for Europe. WHO Regional Office for Europe, Copenhagen, Denmark. 